\title{
Fatty Acids Polyunsaturated as Bioactive Compounds of Microalgae: Contribution to Human Health
}

\author{
Igor Fernandes ${ }^{1,2 *}$ and Rafael Pinto ${ }^{1}$ \\ ${ }^{1}$ Phytoalgae, LDA; São Martinho, Portugal \\ ${ }^{2}$ Oceanic Observatory of Madeira; Regional Agency for the Development of Research Technology and Innovation, Portugal
}

*Corresponding author: Igor Fernandesa, Oceanic Observatory of Madeira; Regional Agency for the Development of Research Technology and Innovation, Funchal, Portugal.
Received Date: June 01, 2019

Published Date: June 14, 2019

\section{Introduction}

Microalgae (i.e. the prokaryotic cyanobacteria and the eukaryotic microalgae) are a wide diversity of microscopic unicellular organisms with the ability to convert solar energy into chemical energy through photosynthesis $[1,2]$. Moreover, this evolutionary and phylogenetic diversity means a great diversity from the point of view of the chemical composition of these organisms. Thus, this makes them extremely attractive for potential exploitation and bioprospecting as commercial sources of a wide range of biomolecules (Table 1) [2].

Table 1: Potential application of biocompounds found in microalgae biomass [7].

\begin{tabular}{|c|c|}
\hline $\begin{array}{c}\text { Biomolecules } \\
\text { activity }\end{array}$ & Application \\
\hline $\begin{array}{c}\text { Nutraceutical, } \\
\text { antimicrobial, anti- } \\
\text { inflamatory }\end{array}$ & $\begin{array}{c}\text { Nutritional supplement, antiproliferative, ability to } \\
\text { combat infections and diseases }\end{array}$ \\
\hline $\begin{array}{c}\text { Antioxidant } \\
\text { (natural pigment) }\end{array}$ & $\begin{array}{c}\text { Supplement and food ingredient for humans, } \\
\text { feeding of fish and shellfish }\end{array}$ \\
\hline Biofuels & $\begin{array}{c}\text { Natural gas production in fermenters via digestion } \\
\text { of biomass to obtain biodiesel }\end{array}$ \\
\hline Fertilizers & Biomass as a source of nitrogen and phosphorous \\
\hline $\begin{array}{c}\text { High-value } \\
\text { molecules }\end{array}$ & $\begin{array}{c}\text { Chlorophyll- } \alpha \text {, phycocyanin, } \beta \text {-carotene, linolenic } \\
\text { acid, eicosapentaenoic acid and stable biochemical } \\
\text { isotopes }\end{array}$ \\
\hline $\begin{array}{c}\text { Anticancer and } \\
\text { antitumor }\end{array}$ & $\begin{array}{c}\text { Antiproliferative. Inducing G1 inhibition in post- } \\
\text { gastric carcinoma cells }\end{array}$ \\
\hline Chemical industry & Volatile organic compounds \\
\hline
\end{tabular}

From among the most biotechnologically relevant microalgae it is worth highlighting the green algae (Chlorophycea) Chlorella vulgaris, Haematococcus pluvialis, Dunaliella salina and the
Cyanobacteria Spirulina maxima which are widely used and commercialized, mainly as nutritional supplements for humans and as animal feed additives [1].

Microalgae are fast growing organisms which could produce a variety of compounds with various commercial uses, namely biodiesel and several compounds industrially produced [3-5]. Moreover, they can be used in the production of energy and to obtain a wide range of metabolites such as proteins, lipids, carbohydrates and minerals for health, food and feed additives and cosmetics [1]. Currently, microalgae play an important role in aquaculture, are used in the enhancement of the nutritional value of food and animal feed due to their chemical composition and can be incorporated into cosmetics [1]. Additionally, microalgae are suitable for use in human health as they are a source of bioactive compounds such as long chain polyunsaturated fatty acids (PUFA), sterols, sugars, pigments, carotenoids, phycobilins and vitamins

$[1,2,6]$. Furthermore, polyunsaturated fatty acid oils are used to obtain nutritional supplements whereas proteins and pigments are important as natural dyes and as compounds which exhibit properties well desired by the pharmaceutical industries to treat certain diseases $[1,7]$. On the other hand, the production of hydrocarbons and saturated and monounsaturated fatty acids by microalgae strains are appropriate for biodiesel production $[4,8]$.

Unlike terrestrial plants, microalgae bring forward several advantages such as a larger biomass production in shorter periods of time which brings out great health benefits, the requirement of less amounts of water and the absence of the application of fungicides, 
herbicides or pesticides during their cultivation [3]. Furthermore, from the environmental point of view, microalgae have great impact on the reduction of greenhouse gases and consequent decrease of global warming, since the production of $1 \mathrm{Kg}$ of dry algal biomass consumes around $1.83 \mathrm{Kg}$ of $\mathrm{CO} 2$ [3].

\section{Importance of Fatty Acids in Health}

Marine microalgae are considered as a renewable source of bioactive lipids with a high proportion of polyunsaturated fatty acids (PUFAs), which have demonstrated to be effective in the prevention or treatment of several diseases [1]. Microalgae exhibit a high percentage of lipids, in which represent approximately $30-50 \%$ of the total weight of biomass [7]. They are suppliers of long-chain PUFAs such as linolenic acid, arachidonic acid, eicosapentaenoic acid (EPA) and docosahexaenoic acid (DHA) [2,9]. EPA and DHA are vital for keeping the bio membranes and cellular functions (e.g. cell signaling), whereas proteins are important for the primary metabolism of microalgae as biological catalysts responsible for crucial reactions that have effect on cell growth [10-12].

PUFAs, namely omega 3 PUFAs such as $\alpha$-linolenic acid (C18:3n-3), EPA (C20:5n-3), docosapentaenoic acid (DPA, C22:5n-3) and DHA (C22:6n-3), have been shown to be effective in the prevention and treatment of cardiovascular diseases, cancer, type 2 diabetes, inflammatory bowel disorders, asthma, arthritis, kidney and skin disorders, depression and schizophrenia [1]. Additionally, the essential fatty acids and the long chain PUFAs are crucial as essential components of the biological membranes and precursors of a wide variety of signaling molecules (e.g. leukotrienes, eicosanoids and thromboxanes), which are responsible for multiple physiological and pathological responses [13-15].

Notwithstanding the multiple advantages offered, humans do not have the ability to synthesize these compounds, so their dietary intake is crucial for human health. Furthermore, research regarding the relations between diet and diseases correlate the dietary intake of these fatty acids with the prevention of cardiovascular diseases and cancer, reduction of coronary heart disease, decrease of mild hypertension and alleviation of the symptoms of rheumatoid arthritis $[6,13,14,16]$.

The knowledge of the ability of PUFA-rich oil from phototrophic microalgae, which is relatively expensive to grow, to compete in the marketplace with the heterotrophically grown algae and fungi, as well as, other PUFA rich oils such as fish oil, either as high-value nutritional supplements or in the lower value market as a fish oil replacement in animal nutrition is not well known [2]. Under these circumstances, the 'vegetable' nature of algae may be a marketing differentiator [2]. To upgrade the future production of algal oils and the combination of diverse improvements in lipid productivity through isolation of new species, strain selection, genetic manipulation and engineering, and/or optimization of culture conditions with economics of scale is essential [2].

\section{Acknowledgments}

This study was supported by project M1420-01-0247FEDER-000023 of Instituto de Desenvolvimento Empresarial da Madeira (IDE, IP-RAM).

\section{Conflict of Interest}

No conflict of interest.

\section{References}

1. Priyadarshani, I, Rath B (2012) Commercial and industrial applications of micro algae-A review. J Algal Biomass Utln 3: 89-100.

2. Borowitzka MA (2013) High-value products from microalgae-their development and commercialisation. J Appl Phycol 25(3): 743-756.

3. Patil AD, Patil N (2015) Mitigation of Global Warming Through Biological Carbon Sequestration Using Micro Algae. Int J Sci Res 4: 1559-1564.

4. Koller M, Muhr A, Braunegg G (2014) Microalgae as versatile cellular factories for valued products. Algal Res 6: 52-63.

5. Ratha SK, Prasanna R, Prasad RBN, Sarika C, Dhar DW, et al. (2013) Modulating lipid accumulation and composition in microalgae by biphasic nitrogen supplementation. Aquaculture 392-395: 69-76.

6. Raposo, MFJ, Morais RM, Morais AM (2013) Health applications of bioactive compounds from marine microalgae. Life Sci 93(15): 479-486.

7. Chew KW, Yap JY, Show PL, Suan NH, Juan JC, et al. (2017) Microalgae biorefinery: High value products perspectives. Bioresour Technol 229: 53-62.

8. Hoffmann M, Marxen K, Schulz R, Vanselow KH (2010) TFA and EPA productivities of Nannochloropsis salina influenced by temperature and nitrate stimuli in turbidostatic controlled experiments. Mar Drugs 8(9): 2526-2545.

9. Chauton MS, Reitan KI, Norsker NH, Tveterås R, Kleivdal HT (2015) A techno-economic analysis of industrial production of marine microalgae as a source of EPA and DHA-rich raw material for aquafeed: Research challenges and possibilities. Aquaculture 436: 95-103.

10. Luo L, Ai L, Li T, Xue M, Wang J, et al. (2015) The impact of dietary DHA/EPA ratio on spawning performance, egg and offspring quality in Siberian sturgeon (Acipenser baeri). Aquaculture 437: 140-145.

11. Sukenik A (1991) Ecophysiological Considerations in the Optimization of Eicosapentaenoic Acid Production by Nannochloropsis sp. (Eustigmatophyceae). Bioresour Technol 35(3): 263-269.

12. Valentine RC, Valentine DL (2004) Omega-3 fatty acids in cellular membranes: a unified concept. Prog Lipid Res 43(5): 383-402.

13. Prato E, Biandolino F (2012) Total lipid contentand fatty acid composition of commercially important fish species from the Mediterranean, Mar Grande Sea. Food Chem 131(4): 1233-1239.

14. Saito H, Aono H (2014) Characteristics of lipid and fatty acid of marine gastropod Turbo cornutus: high levels of arachidonic and n-3 docosapentaenoic acid. Food Chem 145: 135-44.

15. Sirot V, Oseredczuk M, Bemrah Aouachria N, Volatier JL, Leblanc JC (2008) Lipid and fatty acid composition of fish and seafood consumed in France: CALIPSO study. Jj Food Compos Anal 21(1): 8-16.

16. Lund EK (2013) Health benefits of seafood; is it just the fatty acids? Food Chem 140(3): 413-420. 